\title{
Impacts of land disturbance and restoration on runoff production and sediment yield in the Chinese Loess Plateau
}

\author{
AI Ning ${ }^{1,2,3,4}$, WEI Tianxing ${ }^{1}$, ZHU Qingke ${ }^{1 *}$, QIANG Fangfang ${ }^{2}$, MA Huan $^{1}$, QIN Wei ${ }^{3}$ \\ ${ }^{1}$ School of Soil and Water Conservation, Beijing Forestry University, Beijing 100083, China; \\ ${ }^{2}$ College of Life Science, Yan'an University, Yan'an 716000, China; \\ ${ }^{3}$ China Institute of Water Resources and Hydropower Research, Beijing 100048, China; \\ ${ }^{4}$ International Research and Training Center on Erosion and Sedimentation, Beijing 100048, China
}

\begin{abstract}
Land disturbance and land restoration are important factors influencing runoff production and sediment yield in the semi-arid loess regions of China. This study compared the runoff production and sediment yield during the early stage after land disturbance (ESLD) with those during restoring stage after land disturbance (RSLD). Grey relational analysis was used to analyse the importance of each one of the influencing factors (vegetation, rainfall, soil and topography) in affecting the runoff production and sediment yield. Our results showed that during ESLD, topography was the most critical factor controlling the runoff production, while soil was the most important factor controlling the sediment yield. During RSLD, vegetation was more important in affecting runoff production, while rainfall was more important in affecting sediment yield. In additional, this study demonstrated that both the runoff production and the sediment yield can be effectively reduced by restoring vegetation on severely-disturbed lands, thus providing an important theoretical basis for better implementations of the Grain for Green Program. Our results revealed that the vegetation types of Hippophae rhamnoides+Pinus tabulaeformis and H. rhamnoides are better plant selections for land restoration in this area, especially for relatively gentle slopes (i.e., less than 20 degrees).
\end{abstract}

Keywords: land disturbance/restoration; grey relational analysis; runoff; sediment yield; Loess Plateau

Citation: AI Ning, WEI Tianxing, ZHU Qingke, QIANG Fangfang, MA Huan, QIN Wei. 2017. Impacts of land disturbance and restoration on runoff production and sediment yield in the Chinese Loess Plateau. Journal of Arid Land, 9(1): 76-86. doi: 10.1007/s40333-016-0088-6

\section{Introduction}

Land use/cover and land management are considered to be among the most important factors influencing runoff production and soil erosion (Smith and Wischmeier, 1962; Chen et al., 2001; Porto et al., 2009; Tiwari et al., 2009; García-Ruiz, 2010; Nunes et al., 2011; Peng and Wang, 2012), and their importance was abundantly documented in the loess-covered regions (Fu et al., 2000; Wilcox et al., 2003; Chen et al., 2007; Mohammad and Adam, 2010; Li et al., 2015; Zhu et al., 2015). Consequently, land disturbance or/and land mismanagement are sufficiently demonstrated to be key factors enhancing runoff production and soil erosion (Ungar et al., 2010; Mohr et al., 2013; Brunbjerg et al., 2014; Malowerschnig and Sass, 2014; Vanacker et al., 2014). At large spatial scales, such human activities as overgrazing and deforestation are considered as land disturbance or land mismanagement that may enhance runoff production and sediment yield

${ }^{*}$ Corresponding author: ZHU Qingke (E-mail: zhuqingke2015@126.com)

Received 2015-06-05; revised 2016-03-29; accepted 2016-04-05

(C) Xinjiang Institute of Ecology and Geography, Chinese Academy of Sciences, Science Press and Springer-Verlag Berlin Heidelberg 2017 
mainly through altering the vegetation coverage and the soil characteristics (Ludwig et al., 2005; Snyman, 2005; Snyman and Du Preez, 2005; Zheng, 2005, 2006; Zheng et al., 2005; Lin et al., 2010; Taye et al., 2013; Zhao et al., 2013; Ma et al., 2014; Kairis et al., 2015; Gao et al., 2016). At small spatial scales, such human activities as trampling and digging may also enhance runoff production and sediment yield mainly through altering the root system and the micro-topography (Herrick et al., 2010; Dunne et al., 2011; Pohl et al., 2012; Vanacker et al., 2014). Here, we use trampling as an example to illustrate the importance of land disturbance or land mismanagement. Trampling can decrease the soil macro-porosity and the associated hydraulic conductivity, thus increasing runoff production (McDowell et al., 2003; Herrick et al., 2010). Trampling can also damage plant root system, reduce vegetation coverage, and destroy soil structure, thus rendering the soil surface more susceptible to erosion (Dunne et al., 2011; Pohl et al., 2012).

The Chinese Loess Plateau has been notoriously well known to be one of the world's most susceptible regions to soil erosion, and land disturbance and mismanagement were sufficiently demonstrated to have exacerbated soil erosion-related problems. In recent years, with the implementation of the Grain for Green Program and other ecological engineering programs, a great deal of scientific attentions have been focused on the land disturbance or/and land mismanagement and their impacts on runoff production and soil erosion. For example, Zhao et al. (2014) studied the dynamic effects of pastures and crops on runoff production and sediment yield under simulated rainfall conditions and found that vegetation restoration can reduce sediment yield more effectively at the growing stage and can reduce runoff production more effectively at the mature stage. Pan et al. (2006) investigated the influence of grass and moss on runoff production and sediment yield also under simulated rainfall conditions and found that the grass and moss can efficiently reduce sediment yield and runoff production. Wei et al. (2014) studied the effects of surface conditions and rainfall intensities on runoff production using micro-runoff plots and rainfall simulation and concluded that the runoff production varies drastically with different surface conditions and also with different rainfall intensities. Li et al. (2015) investigated the soil detachment capacity and its relationships with sediment yield and runoff production and found that such factors as soil aggregate median diameter, organic matter, and root density can affect soil detachment capacity and thus runoff production and sediment yield.

However, the effects of natural rainfall events on runoff production and sediment yield were found to be dramatically different from the effects of artificial rainfall simulations (Mathys et al., 2005). This study thus attempted to evaluate the effectiveness of the Grain for Green Program by comparing the characteristics of runoff production and sediment yield during the early stage after land disturbance (ESLD) with those during the restoring stage after land disturbance (RSLD) under natural rainfall conditions. The primary objective was to explore the best land restoration strategies for soil and water conservation in the Chinese Loess Plateau.

\section{Materials and methods}

\subsection{Study area}

The study area is Dajigou Catchment (Table 1; Fig. 1), a typical loess hilly area in the northwestern part of the Chinese Loess Plateau within Wuqi County of Shaanxi Province $\left(36^{\circ} 33^{\prime} 33^{\prime \prime}-37^{\circ} 24^{\prime} 27^{\prime \prime} \mathrm{N}, 1^{\circ} 7^{\circ} 38^{\prime} 37^{\prime \prime}-108^{\circ} 32^{\prime} 49^{\prime \prime} \mathrm{E} ; 1233-1809 \mathrm{~m}\right.$ a.s.1.). The mean annual precipitation was about $464.5 \mathrm{~mm}$ (1957-2013), with $61 \%$ falling in the rainy season from July to September. The monthly temperature ranged from $-28.5^{\circ} \mathrm{C}$ (December, 1967) to $38.3^{\circ} \mathrm{C}$ (July, $2001)$, with an annual mean temperature of $7.9^{\circ} \mathrm{C}(1957-2013)$. The surface soils in the study area are of loessial origin with relatively coarse particles (Chronicle, 1991), and the natural vegetation (presumably steppe-dominated) has almost completely disappeared due to a prolonged human disturbance. To restore the severely disturbed ecological environment, Chinese government has recently implemented the Grain for Green Program through vegetation restoration measures. 


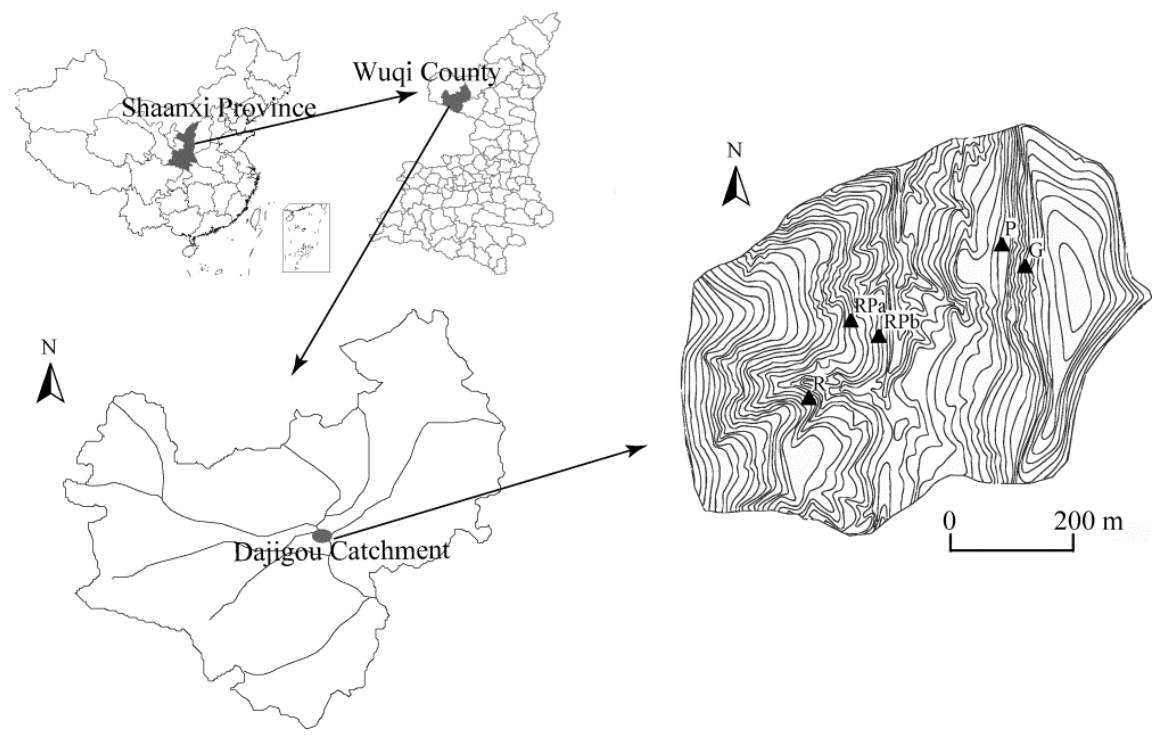

Fig. 1 Location of the study area and distribution of the five plots within Dajigou Catchment. RPa, Hippophae rhamnoides + Pinus tabuliformis; RPb, H. rhamnoides + P. tabuliformis; P, P. tabuliformis; R, H. rhamnoides; G, Lespedeza davurica+Leymus secalinus.

\subsection{Experimental design}

Taking into consideration of the topographical features and the vegetation types, five plots (20 $\mathrm{m} \times 5 \mathrm{~m}$ ) were constructed within the study area in July 2009. The vegetation types in the five plots are: Hippophae rhamnoides + Pinus tabuliformis (Plot RPa), H. rhamnoides + P. tabuliformis (Plot RPb), P. tabuliformis (Plot P), H. rhamnoides (Plot R), and Lespedeza davurica+Leymus secalinus (Plot G) (Table 1; Fig. 1). The vegetation and surface soil were severely disturbed at the five plots through trampling and digging during the construction and we termed the period immediately after the construction the early stage after land disturbance (ESLD). The vegetation and soil conditions at the five plots have gradually ameliorated over time and we termed the period of amelioration the restoring stage after land disturbance (RSLD). Figure 2 shows the condition contrasts between ESLD and RSLD for the Plot G (Figs. 2a and c) and for the Plot P (Figs. 2b and d).

Table 1 Specific conditions of five runoff plots

\begin{tabular}{|c|c|c|c|c|c|c|}
\hline Item & & $\mathrm{RPa}$ & $\mathrm{RPb}$ & $\mathrm{P}$ & $\mathrm{R}$ & G \\
\hline Vegetation type & & $\begin{array}{l}\text { H. rhamnoides } \\
+P . \text { tabuliformis }\end{array}$ & $\begin{array}{l}\text { H. rhamnoides } \\
\text { +P. tabuliformis }\end{array}$ & P. tabuliformis & H. rhamnoides & $\begin{array}{c}\text { Lespedeza } \\
\text { davurica }+ \\
\text { Leymus secalinus }\end{array}$ \\
\hline \multirow{2}{*}{$\begin{array}{l}\text { Density } \\
\text { (plants } / \mathrm{hm}^{2} \text { ) }\end{array}$} & $\begin{array}{l}\text { Pinus } \\
\text { tabuliformis }\end{array}$ & 800 & 700 & 1200 & 2300 & 2. \\
\hline & $\begin{array}{l}\text { Hippophae } \\
\text { rhamnoides }\end{array}$ & 1500 & 1400 & 3000 & 2300 & - \\
\hline Height (m) & & 1.88 & 1.98 & 3.33 & 2.62 & - \\
\hline Slope gradient $\left({ }^{\circ}\right)$ & & 12 & 29 & 17 & 17 & 28 \\
\hline Slope aspect & & $\mathrm{ES} 37^{\circ}$ & $\mathrm{ES} 35^{\circ}$ & $\mathrm{WS} 12^{\circ}$ & $\mathrm{NE} 34^{\circ}$ & $\mathrm{WS}^{\circ}$ \\
\hline Elevation (m) & & 1396 & 1380 & 1386 & 1406 & 1398 \\
\hline \multirow{2}{*}{$\begin{array}{l}\text { Canopy density } \\
(\%)\end{array}$} & ESLD & 48 & 32 & 40 & 35 & 55 \\
\hline & RSLD & 63 & 50 & 53 & 55 & 81 \\
\hline
\end{tabular}

Note: ESLD, early stage after land disturbance; RSLD, restoring stage after land disturbance. 

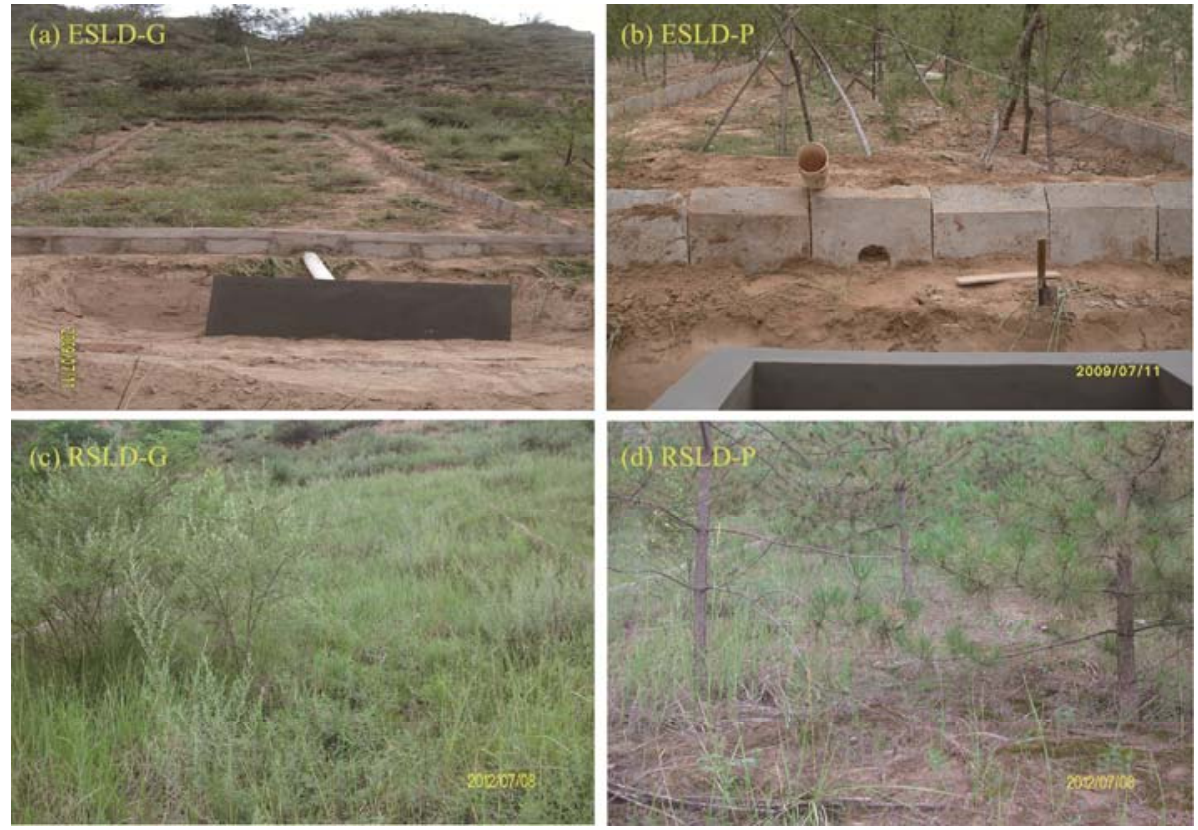

Fig. 2 Condition contrasts between early stage after land disturbance (ESLD) and restoring stage after land disturbance (RSLD) for the Plot G (a and c) and for the Plot P (b and d)

\subsection{Data collections}

At all of the five plots, we monitored the runoff production and sediment yield of each rainfall event during the rainy season (July-September) from 2009 to 2012. At the lower end of each plot, a sump was installed to collect sediment and runoff and the sump was made of concrete with a dimension of $1 \mathrm{~m} \times 1 \mathrm{~m} \times 1 \mathrm{~m}$ (Fig. 3a). A simple automatic meteorological field station (HOBO weather station, Onset Computer Co., Boerne, MA, USA), including a tilting rain gauge, was installed to record year-round meteorological data (Fig. 3b) and the data recording interval was 5 min. The data thus allowed us to calculate the $\mathrm{I}_{5}, \mathrm{I}_{10}, \mathrm{I}_{15}$ and $\mathrm{I}_{30}$ values (note: $\mathrm{I}_{5}, \mathrm{I}_{10}, \mathrm{I}_{15}$ and $\mathrm{I}_{30}$ were the maximum rainfall intensities for 5-min, 10-min, 15-min and 30-min, respectively).
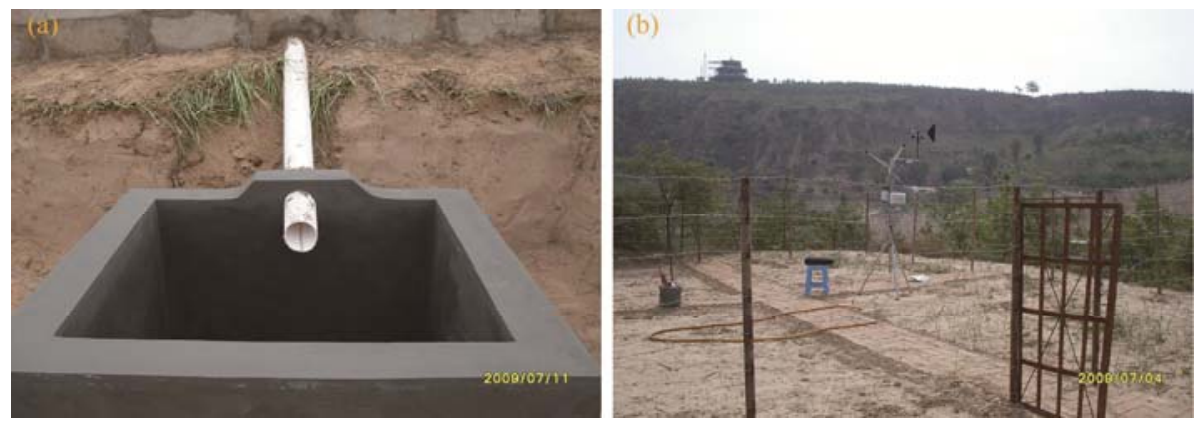

Fig. 3 Sediment and runoff collecting sump (a) and automatic meteorological station (b)

\subsection{Soil hydraulic properties}

Three soil pits were excavated at the uphill, middle and downhill sites and soil samples were collected from each pit at the depths of 0-20, 20-40, 40-60, 60-80 and 80-100 cm. Soil bulk densities were tested using a ring knife with a diameter of $5 \mathrm{~cm}$ and a height of $5 \mathrm{~cm}$. Soil infiltration apparatus was employed for recording the process of water infiltration into the soil and the depth of infiltration was calculated by an empirical Equation 1.

$$
H=0.19635 \times h \times \cos a \text {. }
$$


Where $H$ is the depth of infiltration; $h$ is the change in the standing water level; and $a$ is the slope gradient. At the beginning of the experiment, data were recorded every $10 \mathrm{~s}$ for $90 \mathrm{~s}$; then, data were recorded every $30 \mathrm{~s}$ for $5 \mathrm{~min}$; at the end, data were recorded once one minute. The experiment were repeated for 5-6 times to insure data consistency (Zhao et al., 2010).

\subsection{Data processing}

We used the Principal Coordinates Analysis method to convert the qualitative variables, such as vegetation and slope aspect, into quantitative variables (Zhang, 2004) to obtain the characteristic value of each variable. And, we then used the characteristic value for further analysis and the further analysis was carried out using the grey correlation method (Deng, 2002). This grey correlation method identifies the similarity or dissimilarity of the development trends among factors. By comparing a sequence of an established family of curves with a reference sequence curve using geometric similarity, one can determine the degree of connection between the reference sequence and the comparing sequence. It means that the more similar, the greater degree the similarity is. The comparing sequence and the reference sequence can be both temporal series and non-temporal series. The method is shown as below:

$$
x_{i}^{\prime}(\mathrm{k})=\frac{x_{i}(\mathrm{k})-\min x_{i}(\mathrm{k})}{\max x_{i}(\mathrm{k})-\min x_{i}(\mathrm{k})} .
$$

Where $x_{i}^{\prime}(\mathrm{k})$ are the new values obtained when the parameters are standardized by Equation 2, and $x_{i}(\mathrm{k})$ are the original parameters.

The correlation coefficient is calculated by Equations 3-6.

$$
\begin{gathered}
\gamma\left(x_{0}^{\prime}(\mathrm{k}), x_{i}^{\prime}(\mathrm{k})\right)=\frac{\Delta x_{\min }+\xi \Delta x_{\max }}{\Delta x_{0 i}(\mathrm{k})+\xi \Delta x_{\max }} . \\
\Delta x_{\min }=\min _{\forall j \in i} \min _{\forall k}\left|x_{0}^{\prime}(\mathrm{k})-x_{j}^{\prime}(\mathrm{k})\right| . \\
\Delta x_{\max }=\max _{\forall j \in i} \max _{\forall k}\left|x_{0}^{\prime}(\mathrm{k})-x_{j}^{\prime}(\mathrm{k})\right| . \\
\Delta x_{0 i}(\mathrm{k})=\left|x_{0}^{\prime}(\mathrm{k})-x_{i}^{\prime}(\mathrm{k})\right| .
\end{gathered}
$$

Where $\Delta x_{0 i}(\mathrm{k})$ is the absolute value of the difference between the comparing sequence and the reference sequence and $\xi$ is the distinguishing coefficient. The value of $\xi$ ranges from 0 to 1 , but $\xi=0.5$ is considered to be a threshold for showing similarity. $\gamma\left(x_{0}^{\prime}(\mathrm{k}), x_{i}^{\prime}(\mathrm{k})\right)$ is the correlation coefficient.

The grey relational grade $(\mathrm{GRG}, \Gamma)$ is calculated by Equation 7 .

$$
\Gamma=\frac{1}{n} \sum_{\mathrm{k}=1}^{n} \gamma\left(x_{0}^{\prime}(\mathrm{k}), x_{i}^{\prime}(\mathrm{k})\right) .
$$

We selected runoff production and sediment yield as the reference sequences and used several indicators as our comparing sequences. The used comparing sequences include vegetation type, vegetation coverage, rainfall amount, rainfall duration, average rainfall intensity, $\mathrm{I}_{5}, \mathrm{I}_{10}, \mathrm{I}_{15}, \mathrm{I}_{30}$, soil bulk density, soil infiltration rate, and slope aspect, and gradient. Then, the GRG was calculated for the references and the comparing sequences (Tables 2 and 3). According to Deng (2002), a larger GRG means a closer relationship between the comparing sequence and the reference sequences.

\section{Results}

\subsection{Factors affecting runoff production}

As shown in Table 2, the slope aspect had the strongest impact on the runoff production with a GRG of 0.6681 during ESLD. The second rank was the soil infiltration rate with a GRG of 0.6524 . The rainfall amount ranked as the third with a GRG of 0.6417 , followed by rainfall duration with a GRG of 0.6303 . Among the rainfall intensities, $\mathrm{I}_{15}$ had the largest GRG (0.6209). 
The influences of vegetation type and cover on the runoff were at the intermediate ranks among the 13 considered factors. It should be noted that the smallest GRG value of $0.5406\left(\mathrm{I}_{30}\right)$ was still larger than the presumed threshold of 0.5 , meaning that all the 13 considered factors were closely related to the runoff production.

During RSLD (Table 2), the rainfall duration with a GRG of 0.7443 replaced the slope aspect as the most critical factor affecting the runoff production. The vegetation type ranked the second with a GRG of 0.6757 and the rainfall amount ranked the third with a GRG of 0.6415 . The GRG of the soil steady infiltration rate ranked the fourth $(\mathrm{GRG}=0.6231)$. Among the rainfall intensities, $\mathrm{I}_{10}$ was the most critical factor with a GRG of 0.6186. The influence of slope aspect on the runoff production during RSLD (eleventh rank) was much less important than during ESLD (first rank).

Table 2 Grey relational grade between runoff and its influential factors

\begin{tabular}{|c|c|c|c|c|c|c|c|}
\hline & & \multicolumn{3}{|c|}{ ESLD } & \multicolumn{3}{|c|}{ RSLD } \\
\hline & & GRG & Rank & Proportion (\%) & GRG & Rank & Proportion (\%) \\
\hline \multirow[t]{2}{*}{ Vegetation } & Vegetation type & 0.6133 & 6 & \multirow{2}{*}{24.76} & 0.6757 & 2 & \multirow{2}{*}{25.94} \\
\hline & Vegetation coverage & 0.6023 & 7 & & 0.6061 & 8 & \\
\hline \multirow[t]{7}{*}{ Rainfall } & Rainfall amount & 0.6417 & 3 & \multirow{7}{*}{24.11} & 0.6415 & 3 & \multirow{7}{*}{25.39} \\
\hline & Rainfall duration & 0.6303 & 4 & & 0.7443 & 1 & \\
\hline & $\begin{array}{l}\text { Average rainfall } \\
\text { intensity }\end{array}$ & 0.5835 & 10 & & 0.5675 & 12 & \\
\hline & $\mathrm{I}_{5}$ & 0.5584 & 12 & & 0.6146 & 7 & \\
\hline & $\mathrm{I}_{10}$ & 0.5662 & 11 & & 0.6186 & 5 & \\
\hline & $\mathrm{I}_{15}$ & 0.6209 & 5 & & 0.6032 & 9 & \\
\hline & $\mathrm{I}_{30}$ & 0.5406 & 13 & & 0.6012 & 10 & \\
\hline \multirow[t]{2}{*}{ Soil } & Soil bulk density & 0.5936 & 9 & \multirow[b]{2}{*}{25.39} & 0.5665 & 13 & \multirow[b]{2}{*}{24.08} \\
\hline & $\begin{array}{l}\text { Soil steady } \\
\text { infiltration }\end{array}$ & 0.6524 & 2 & & 0.6231 & 4 & \\
\hline \multirow[t]{2}{*}{ Topography } & Slope aspect & 0.6681 & 1 & \multirow{2}{*}{25.74} & 0.5995 & 11 & \multirow{2}{*}{24.59} \\
\hline & Slope gradient & 0.5955 & 8 & & 0.6156 & 6 & \\
\hline
\end{tabular}

Note: $\mathrm{I}_{5}, 5$-min maximum rainfall intensity; $\mathrm{I}_{10}, 10$-min maximum rainfall intensity; $\mathrm{I}_{15}, 15$-min maximum rainfall intensity; $\mathrm{I}_{30}, 30$-min maximum rainfall intensity; GRG, grey relational grade.

\subsection{Factors affecting sediment yield}

Table 3 shows that the soil bulk density was the dominant factor affecting sediment yield during ESLD and the GRG was as high as 0.8113 . The average rainfall intensity ranked the second with a GRG of 0.7444 , followed by the soil steady infiltration rate $(\mathrm{GRG}=0.7128)$. Among the rainfall intensities, $\mathrm{I}_{30}$ had the closest relationship with sediment yield $(\mathrm{GRG}=0.6890)$. The $\mathrm{GRG}$ was 0.6487 for vegetation type and 0.6229 for vegetation coverage. The smallest GRG value of 0.5945 (slope gradient) was larger than the presumed threshold of 0.5 , indicating that all of the considered 14 factors had close relationships with the sediment yield (note: runoff was added as an additional factor to the 13 factors listed in Table 2).

During RSLD, the four-grade rainfall intensities were all among the most significant factors, e.g., $I_{5}$ ranked the second $(G R G=0.7953), I_{10}$ the first $(G R G=0.8012), I_{15}$ the third $(G R G=0.7779)$, and $I_{30}$ the fourth $(G R G=0.7593)$, indicating that rainfall intensity was the most important in influencing the sediment yield during RSLD. Similarly, the rainfall duration was promoted from rank tenth during ESLD to rank fifth during ESLD. By comparison, the soil bulk density was demoted from rank first during ESLD to rank tenth during RSLD. At the same time, the importance of the soil steady infiltration rate was demoted from rank third during ESLD to rank eighth during RSLD and the importance of runoff was promoted from rank thirteenth during ESLD to rank eleventh during RSLD. The importance of both the vegetation type and vegetation coverage on sediment yield was lowered during RSLD compared with that during ESLD. 


\subsection{Runoff production and sediment yield under different vegetation types}

Significant differences were observed under the different vegetation types in terms of runoff production and sediment yield between ESLD and RSLD (Fig. 4). The runoff production and sediment yield during ESLD were remarkably higher than those during RSLD. For example, the runoff production was 13.55-fold higher during ESLD than during RSLD and the sediment yield was 3.13-fold higher during ESLD than during RSLD under forest conditions (e.g., Plot P). The runoff production and sediment yield were 8.59-fold and 1.70-fold higher during ESLD than during RDLS, respectively, under grassland conditions (e.g., Plot G). Under mixed vegetation conditions (e.g., Plots $\mathrm{RPa}, \mathrm{RPb}$, and $\mathrm{R}$ ), the runoff production was 3 5 times higher during ESLD than during RSLD and the sediment yield was 1 2 times higher during ESLD than during RSLD. The analytical results demonstrate that vegetation restoration can effectively reduce the runoff production and sediment yield.

Table 3 Grey relational grade between sediment yield and its influential factors

\begin{tabular}{|c|c|c|c|c|c|c|c|}
\hline & & \multicolumn{3}{|c|}{ ESLD } & \multicolumn{3}{|c|}{ RSLD } \\
\hline & & GRG & Rank & Proportion (\%) & GRG & Rank & Proportion $(\%)$ \\
\hline Runoff & Runoff & 0.6129 & 13 & 18.62 & 0.6323 & 11 & 19.32 \\
\hline \multirow[t]{2}{*}{ Vegetation } & Vegetation type & 0.6487 & 7 & \multirow{2}{*}{19.31} & 0.6119 & 13 & \multirow{2}{*}{18.73} \\
\hline & Vegetation coverage & 0.6229 & 11 & & 0.6141 & 12 & \\
\hline \multirow[t]{7}{*}{ Rainfall } & Rainfall amount & 0.6198 & 12 & \multirow{7}{*}{20.22} & 0.6627 & 9 & \multirow{7}{*}{22.54} \\
\hline & Rainfall duration & 0.6316 & 10 & & 0.6926 & 5 & \\
\hline & Average rainfall intensity & 0.7444 & 2 & & 0.6758 & 6 & \\
\hline & $\mathrm{I}_{5}$ & 0.6668 & 5 & & 0.7953 & 2 & \\
\hline & $\mathrm{I}_{10}$ & 0.6595 & 6 & & 0.8012 & 1 & \\
\hline & $\mathrm{I}_{15}$ & 0.6482 & 8 & & 0.7779 & 3 & \\
\hline & $\mathrm{I}_{30}$ & 0.6890 & 4 & & 0.7593 & 4 & \\
\hline \multirow[t]{2}{*}{ Soil } & Soil bulk density & 0.8113 & 1 & \multirow{2}{*}{23.15} & 0.6532 & 10 & \multirow{2}{*}{20.14} \\
\hline & Soil steady infiltration rate & 0.7128 & 3 & & 0.6652 & 8 & \\
\hline \multirow[t]{2}{*}{ Topography } & Slope aspect & 0.6362 & 9 & \multirow{2}{*}{18.69} & 0.6658 & 7 & \multirow{2}{*}{19.26} \\
\hline & Slope gradient & 0.5945 & 14 & & 0.5949 & 14 & \\
\hline
\end{tabular}

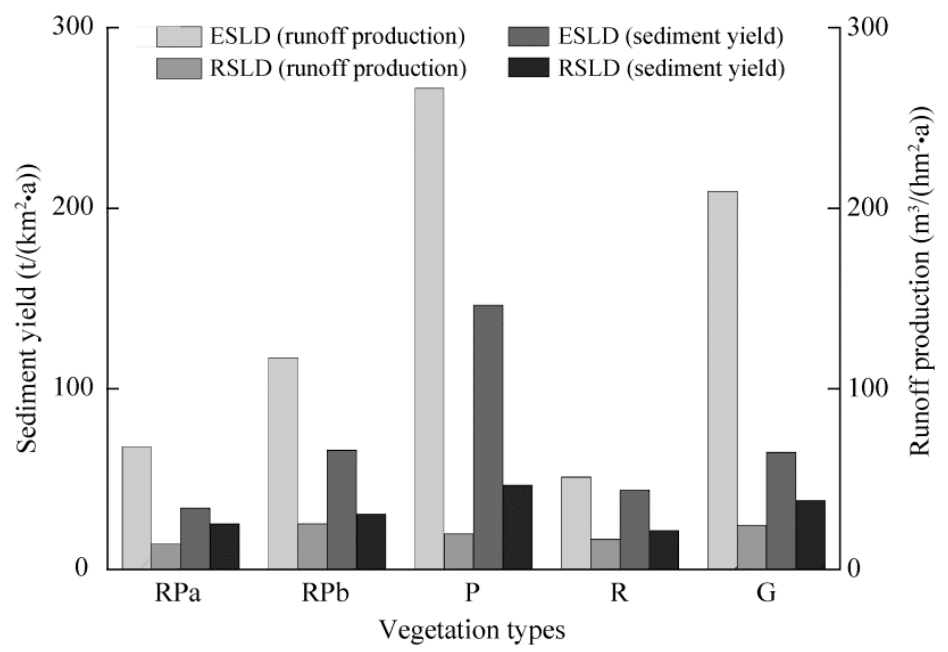

Fig. 4 Runoff production and sediment yield during ESLD and during RSLD for five different vegetation types 


\section{Discussion}

\subsection{Effects of land disturbance and restoration on runoff production}

The importance of different factors on runoff production differed significantly during ESLD than during RSLD. The importance of the major factors had a descending order during ESLD as follow: topography $>$ soil $>$ vegetation $>$ rainfall, and the descending order during RSLD became: vegetation $>$ rainfall $>$ topography $>$ soil (see Table 2). In this study, the surface soil was severely disturbed and the vegetation was greatly reduced during the plot construction. When the surface soil was disturbed or/and compacted and the vegetation coverage was reduced or removed, the soil steady infiltration rate and the canopy interception capacity were reduced, leading to increase in runoff production (Wilcox et al., 2003; Zhang et al., 2009; Wei et al., 2014). It should be stressed that vegetation root systems can improve the soil infiltration capacity and that the soil disturbance-resulted destruction of the root systems can increase runoff production through decreasing the soil steady infiltration rate (Gyssels et al., 2005; Wang et al., 2013, 2014a, b). Another point needs addressing here. That is, the importance of vegetation types on runoff production was relatively weak during ESLD (see Table 2) and the speculated reason is that the interception and retention capacities were rather limited at all five plots during ESLD simply due to rather limited vegetation coverage immediately after the plot construction. Consequently, rainfall became more important (the fourth rank) simply due to the reduced interception and retention capacities (Ai et al., 2013).

Researchers have extensively explored the effects of land disturbance on runoff production and sediment yield and the published literatures have provided more details that are quite relevant to our study. For example, Wilcox et al. (2003) and Vanacker et al. (2014) noted that surface soil disturbances can modify surface topographical features and the vegetation patch structure, eventually decreasing water storage or retention capacity on the hillslope. Mohr et al. (2013) found that the impact of micro-topography on surface runoff connectivity and water-repellent properties is the first-order control on hydrological and soil erosion processes. Similarly, Researchers have also extensively explored the effects of land restoration on runoff production and sediment yield and the published literatures have provided more details that are also quite relevant to our study. For example, plant growth can reduce raindrop energy and total runoff depth through canopy interception and stemflow (Wei et al., 2007; Návar, 2011; Yang et al., 2013). Vegetation recovery can improve soil conditions, such as soil permeability and soil water storage capacity and can also reduce runoff production through root-network development and litter accumulation (Gyssels et al., 2005; Descheemaeker et al., 2006; Huang et al., 2013). Our study sufficiently demonstrated that vegetation restoration can effectively conserve both water and soil. For example, the runoff production was 13.55-fold lower during RSLD than during ESLD under forest conditions (e.g., Plot P). Our study (see Table 3) confirmed the earlier reports that the vegetation restoration became increasingly important for reducing runoff production once topographical features were stabilized and that rainfall duration and rainfall intensity were the dominant factors influencing runoff production under fully-restored vegetation condition (Wei et al., 2007, 2009, 2014).

\subsection{Effects of land disturbance and restoration on sediment yield}

The importance of the major factors affecting sediment yield also differed significantly between ESLD and RSLD. The descending order of the importance during ESLD was as follow: soil $>$ rainfall $>$ vegetation $>$ topography $>$ runoff (see Table 3 ). The descending order during RSLD was as follow: rainfall $>$ soil $>$ runoff $>$ topography $>$ vegetation. The published literatures demonstrated that removal of the vegetation and disturbance of the surface soil can degrade soil structures, thus encouraging sediment movement (Vacher et al., 2003; Porto et al., 2009). Some scholars have shown that the soil surface can be stabilized with a vegetation coverage $>60 \%$ and thus reduce soil erosion (Martin et al., 2010; Pohl et al., 2012). Our study further elaborated those points. For example, the sediment yield was 3.13-fold lower during RSLD than during ESLD under forest conditions (see Table 3). 


\subsection{Influence of vegetation type on runoff and sediment yield}

As stated earlier, significant differences were observed under the different vegetation types in terms of runoff production and sediment yield between ESLD and RSLD, being consistent with the reported observations by other scholars (Fu et al., 2000; Vacca et al., 2000; Meng et al., 2008; Xu et al., 2008; Xu et al., 2009; Mohammad and Adam, 2010; Wang et al., 2011; Ai et al., 2013; Wei et al., 2014). Although the runoff production and sediment yield differed significantly under different vegetation types, the variable coefficient for RSLD was lower than that for ESLD under all vegetation types (see Fig. 4). It simply means that the effect of vegetation type on sediment yield was more important during ESLD than during RSLD. In addition, some scholars have attempted to search for the best plant species or the combinations for land restoration. For example, Wei et al. (2014) found that shrub species were better than grass species for retaining runoff and reducing sediment yield in a loess hilly area in China. This study concluded that RPa (H. rhamnoides $+P$. tabuliformis) and $\mathrm{R}$ (H. rhamnoides) are better choices for land restoration in this area, especially for relatively gentle slopes (i.e., less than 20 degrees).

\section{Conclusions}

Land disturbance and restoration significantly influence the runoff production and sediment yield. The importance of each one of the influencal factors (vegetation, rainfall, soil, and topography) was so different during ESLD in comparison with those during RSLD. This study demonstrated that both the runoff production and the sediment yield can be effectively reduced by restoring vegetation on severely-disturbed lands, thus providing an important theoretical basis for better implementations of the Grain for Green Program. Our findings revealed that $\mathrm{RPa}(H$. rhamnoides $+P$. tabuliformis) and $\mathrm{R}(H$. rhamnoides) vegetation types are better plant selections for land restoration in this area, especially for relatively gentle slopes (i.e., less than 20 degrees).

\section{Acknowledgements}

This study was funded by the National Science and Technology Support Plan of China (2015BAD07B02). We would like to thank ZHAO Jian, ZHOU Yi and WANG Xiaowei for their valuable comments on this manuscript. We also thank the anonymous reviewers and editors for their constructive comments and suggestions.

\section{References}

Ai N, Wei T X, Zhu Q K. 2013. The effect of rainfall for runoff-erosion-sediment yield under the different vegetation types in loess plateau of northern Shaanxi Province. Journal of Soil and Water Conservation, 27(2): 26-30, 35. (in Chinese)

Brunbjerg A K, Svenning J C, Ejrnaes R. 2014. Experimental evidence for disturbance as key to the conservation of dune grassland. Biological Conservation, 174: 101-110.

Chen L D, Wang J, Fu B J, et al. 2001. Land-use change in a small catchment of northern Loess Plateau, China. Agriculture, Ecosystems \& Environment, 86(2): 163-172.

Chen L D, Huang Z L, Gong J, et al. 2007. The effect of land cover/vegetation on soil water dynamic in the hilly area of the Loess Plateau, China. Catena, 70(2): 200-208.

Descheemaeker K, Muys B, Nyssen J, et al. 2006. Litter production and organic matter accumulation in enclosures of the Tigray highlands, Ethiopia. Forest Ecology and Management, 233(1): 21-35.

Dunne T, Western D, Dietrich W E. 2011. Effects of cattle trampling on vegetation, infiltration, and erosion in a tropical rangeland. Journal of Arid Environments, 75(1): 58-69.

Fu B J, Chen L D, Ma K M, et al. 2000. The relationships between land use and soil conditions in the hilly area of the loess plateau in northern Shaanxi, China. Catena, 39(1): 69-78.

Gao H D, Li Z B, Jia L L, et al. 2016. Capacity of soil loss control in the Loess Plateau based on soil erosion control degree. Journal of Geographical Sciences, 26(4): 457-472.

García-Ruiz J M. 2010. The effects of land uses on soil erosion in Spain: a review. Catena, 81(1): 1-11.

Gyssels G, Poesen J, Bochet E, et al. 2005. Impact of plant roots on the resistance of soils to erosion by water: a review. Progress in Physical Geography, 29(2): 189-217. 
Herrick J E, Van Zee J W, Belnap J, et al. 2010. Fine gravel controls hydrologic and erodibility responses to trampling disturbance for coarse-textured soils with weak cyanobacterial crusts. Catena, 83(2-3): 119-126.

Huang J, Wu P T, Zhao X N. 2013. Effects of rainfall intensity, underlying surface and slope gradient on soil infiltration under simulated rainfall experiments. Catena, 104: 93-102.

Kairis O, Karavitis C, Salvati L, et al. 2015. Exploring the impact of overgrazing on soil erosion and land degradation in a dry Mediterranean agro-forest landscape (Crete, Greece). Arid Land Research and Management, 29(3): 360-374.

Li Z W, Zhang G H, Geng R, et al. 2015. Land use impacts on soil detachment capacity by overland flow in the Loess Plateau, China. Catena, 124: 9-17.

Lin Y, Han G D, Zhao M L, et al. 2010. Spatial vegetation patterns as early signs of desertification: a case study of a desert steppe in Inner Mongolia, China. Landscape Ecology, 25(10): 1519-1527.

Ludwig J A, Wilcox B P, Breshears D D, et al. 2005. Vegetation patches and runoff-erosion as interacting ecohydrological processes in semiarid landscapes. Ecology, 86(2): 288-297.

Ma L, Teng Y G, Shangguan Z P. 2014. Ecohydrological responses to secondary natural Populus davidiana and plantation Pinus tabulaeformis woodlands on the Loess Plateau of China. Ecohydrology, 7(2): 612-621.

Malowerschnig B, Sass O. 2014. Long-term vegetation development on a wildfire slope in Innerzwain (Styria, Austria). Journal of Forestry Research, 25(1): 103-111.

Martin C, Pohl M, Alewell C, et al. 2010. Interrill erosion at disturbed alpine sites: effects of plant functional diversity and vegetation coverage. Basic and Applied Ecology, 11(7): 619-626.

Mathys N, Klotz S, Esteves M, et al. 2005. Runoff and erosion in the black marls of the French Alps: observations and measurements at the plot scale. Catena, 63(2-3): 261-281.

McDowell R W, Drewry J J, Paton R J, et al. 2003. Influence of soil treading on sediment and phosphorus losses in overland flow. Australian Journal of Soil Research, 41(5): 949-961.

Meng Q H, Fu B J, Tang X P, et al. 2008. Effects of land use on phosphorus loss in the hilly area of the Loess Plateau, China. Environmental Monitoring and Assessment, 139(1-3): 195-204.

Mohammad A G, Adam M A. 2010. The impact of vegetative cover type on runoff and soil erosion under different land uses. Catena, 81(2): 97-103.

Mohr C H, Coppus R, Iroumé A, et al. 2013. Runoff generation and soil erosion processes after clear cutting. Journal of Geophysical Research: Earth Surface, 118(2): 814-831.

Návar J. 2011. Stemflow variation in Mexico's northeastern forest communities: its contribution to soil moisture content and aquifer recharge. Journal of Hydrology, 408(1-2): 35-42.

Nunes A N, de Almeida A C, Coelho C O A. 2011. Impacts of land use and cover type on runoff and soil erosion in a marginal area of Portugal. Applied Geography, 31(2): 687-699.

Pan C Z, Shangguan Z P, Lei T W. 2006. Influences of grass and moss on runoff and sediment yield on sloped loess surfaces under simulated rainfall. Hydrological Processes, 20(18): 3815-3824.

Peng T, Wang S J. 2012. Effects of land use, land cover and rainfall regimes on the surface runoff and soil loss on karst slopes in southwest China. Catena, 90: 53-62.

Pohl M, Graf F, Buttler A, et al. 2012. The relationship between plant species richness and soil aggregate stability can depend on disturbance. Plant and Soil, 355(1-2): 87-102.

Porto P, Walling D E, Callegari G. 2009. Investigating the effects of afforestation on soil erosion and sediment mobilization in two small catchments in Southern Italy. Catena, 79(3): 181-188.

Smith D D, Wischmeier W H. 1962. Rainfall erosion. Advances in Agronomy, 14: 109-148.

Snyman H A. 2005. Rangeland degradation in a semi-arid South Africa-I: influence on seasonal root distribution, root/shoot ratios and water-use efficiency. Journal of Arid Environments, 60(3): 457-481.

Snyman H A, du Preez C C. 2005. Rangeland degradation in a semi-arid South Africa-II: influence on soil quality. Journal of Arid Environments, 60(3): 483-507.

Taye G, Poesen J, Van Wesemael B, et al. 2013. Effects of land use, slope gradient, and soil and water conservation structures on runoff and soil loss in semi-arid Northern Ethiopia. Physical Geography, 34(3): 236-259.

Tiwari K R, Sitaula B K, Bajracharya R M, et al. 2009. Runoff and soil loss responses to rainfall, land use, terracing and management practices in the middle mountains of Nepal. Acta Agriculturae Scandinavica, Section B-Soil \& Plant Science, 59(3): 197-207.

Ungar E D, Stavi I, Lavee H, et al. 2010. Effects of livestock traffic on rock fragment movement on hillsides in a semiarid patchy rangeland. Land Degradation \& Development, 21(2): 92-99.

Vacca A, Loddo S, Ollesch G, et al. 2000. Measurement of runoff and soil erosion in three areas under different land use in 
Sardinia (Italy). Catena, 40(1): 69-92.

Vacher C A, Loch R J, Raine S R. 2003. Effect of polyacrylamide additions on infiltration and erosion of disturbed lands. Australian Journal of Soil Research, 41(8): 1509-1520.

Vanacker V, Bellin N, Molina A, et al. 2014. Erosion regulation as a function of human disturbances to vegetation coverage: a conceptual model. Landscape Ecology, 29(2): 293-309.

Wang B, Zhang G H, Shi Y Y, et al. 2013. Effect of natural restoration time of abandoned farmland on soil detachment by overland flow in the Loess Plateau of China. Earth Surface Processes and Landforms, 38(14): 1725-1734.

Wang B, Zhang G H, Shi Y Y, et al. 2014a. Soil detachment by overland flow under different vegetation restoration models in the Loess Plateau of China. Catena, 116: 51-59.

Wang B, Zhang G H, Zhang X C, et al. 2014b. Effects of near soil surface characteristics on soil detachment by overland flow in a natural succession grassland. Soil Science Society of America Journal, 78(2): 589-597.

Wang L, Wei S P, Horton R, et al. 2011. Effects of vegetation and slope aspect on water budget in the hill and gully region of the Loess Plateau of China. Catena, 87(1): 90-100.

Wei W, Chen L D, Fu B J, et al. 2007. The effect of land uses and rainfall regimes on runoff and soil erosion in the semi-arid loess hilly area, China. Journal of Hydrology, 335(3-4): 247-258.

Wei W, Chen L D, Fu B J, et al. 2009. Responses of water erosion to rainfall extremes and vegetation types in a loess semiarid hilly area, NW China. Hydrological Processes, 23(12): 1780-1791.

Wei W, Jia F Y, Yang L, et al. 2014. Effects of surficial condition and rainfall intensity on runoff in a loess hilly area, China. Journal of Hydrology, 513: 115-126.

Wilcox B P, Breshears D D, Allen C D. 2003. Ecohydrology of a resource-conserving semiarid woodland: effects of scale and disturbance. Ecological Monographs, 73(2): 223-239.

Xu X L, Ma K M, Fu B J, et al. 2008. Influence of three plant species with different morphologies on water runoff and soil loss in a dry-warm river valley, SW China. Forest Ecology and Management, 256(4): 656-663.

Xu X L, Ma K M, Fu B J, et al. 2009. Soil and water erosion under different plant species in a semiarid river valley, SW China: the effects of plant morphology. Ecological Research, 24(1): 37-46.

Yang F S, Cao M M, Li H E, et al. 2013. Simulation of sediment retention effects of the single seabuckthorn flexible dam in the Pisha Sandstone area. Ecological Engineering, 52: 228-237.

Zhang G H, Tang M K, Zhang X C. 2009. Temporal variation in soil detachment under different land uses in the loess plateau of China. Earth Surface Processes and Landforms, 34(9): 1302-1309.

Zhao G, Mu X, Wen Z, et al. 2013. Soil erosion, conservation, and eco-environment changes in the loess plateau of China. Land Degradation \& Development, 24(5): 499-510.

Zhao J, Wei T X, Chen Z F, et al. 2010. Soil and water conservation benefit analysis for different vegetation in young forests converted by farmland of Wuqi County in Shaanxi province. Journal of Soil and Water Conservation, 24(3): 31-34, 49. (in Chinese)

Zhao X N, Huang J, Wu P T, et al. 2014. The dynamic effects of pastures and crop on runoff and sediments reduction at loess slopes under simulated rainfall conditions. Catena, 119: 1-7.

Zheng F L. 2005. Effects of accelerated soil erosion on soil nutrient loss after deforestation on the loess plateau. Pedosphere, 15(6): 707-715.

Zheng F L, He X B, Gao X T, et al. 2005. Effects of erosion patterns on nutrient loss following deforestation on the Loess Plateau of China. Agriculture, Ecosystems \& Environment, 108(1): 85-97.

Zheng F L. 2006. Effect of vegetation changes on soil erosion on the Loess Plateau. Pedosphere, 16(4): $420-427$.

Zhu J L, Gao P, Geissen V, et al. 2015. Impacts of rainfall and land use on sediment regime in a semi-arid region: case study of the Wuqi catchment in the upper Beiluo river basin, China. Arid Land Research and Management, 29(1): 1-16. 